\title{
New insights into the microbiota of wild mice
}

\author{
Ho-Keun Kwon ${ }^{1}$ · Je Kyung Seong $2,3,4$ (I)
}

Received: 26 February 2021 / Accepted: 15 June 2021 / Published online: 9 July 2021

(c) The Author(s) 2021

\begin{abstract}
Laboratory mice have long been an invaluable tool in biomedical science and have made significant contributions in research into life-threatening diseases. However, the translation of research results from mice to humans often proves difficult due to the incomplete nature of laboratory animal-based research. Hence, there is increasing demand for complementary methods or alternatives to laboratory mice that can better mimic human physiological traits and potentially bridge the translational research gap. Under these circumstances, the natural/naturalized mice including "wild", "dirty", "wildling", and "wilded" systems have been found to better reflect some aspects of human pathophysiology. Here, we discuss the pros and cons of the laboratory mouse system and contemplate how wild mice and wild microbiota are able to help in refining such systems to better mimic the real-world situation and contribute to more productive translational research.
\end{abstract}

Laboratory mice (lab mice) are a mainstay in current biomedical science that have contributed to pivotal discoveries leading to the development of life-saving therapeutics (Kleinert et al. 2018; Rust 1982). The main advantage of using lab mice is the ability to control genetic and environmental factors, which are key determinants for the experimental outcome of biomedical research. The use of lab mice, mainly comprising a wide range of inbred strains, enables researchers to control and even manipulate their genetic components, permitting the elucidation of the causal relationship between the gene and the specific phenotype of cells and/or animals. At the same time, the standardized environmental conditions in the present-day animal vivarium

Je Kyung Seong

snumouse@snu.ac.kr

1 Department of Microbiology and Immunology, Institute for Immunology and Immunological Diseases and Brain Korea 21 PLUS Project for Medical Sciences, Yonsei University College of Medicine, Seoul, Korea

2 Laboratory of Developmental Biology and Genomics, Research Institute for Veterinary Science, and BK 21 PLUS Program for Creative Veterinary Science Research, College of Veterinary Medicine, Seoul National University, Seoul 08826, South Korea

3 Interdisciplinary Program for Bioinformatics, Program for Cancer Biology and BIO-MAX/N-Bio Institute, Seoul National University, Seoul 08826, South Korea

4 Korea Mouse Phenotyping Center (KMPC), Seoul National University, Seoul 08826, South Korea are tightly controlled and have led to synchronization of the majority of environmental factors (for example, day/night cycle, temperature, diet, and water supplementation, etc.), which potentially affects the experimental outcome. (Reza Khorramizadeh and Saadat 2020). Moreover, lab mice can be maintained in an artificial microbial environment, known as specific pathogen free (SPF), in which the exposure of lab mice to the major pathosymbiotics (bacteria, viruses, fungi, and worms) is highly restricted compared with that of mice in a natural habitat (Nguyen et al. 2015). These advantages of the laboratory mouse system have drastically enhanced the reproducibility of biomedical research and have allowed researchers to leverage a "one gene-one disease" paradigm.

However, there is growing concern for the validity of laboratory animal models that do not properly manifest human pathophysiological traits (Mak et al. 2014; Pedersen and Babayan 2011; Seok et al. 2013). For example, despite the astronomical costs of animal model-based preclinical research, the overall success rate of subsequent drug development trials is just 14\% (Wong et al. 2019). Furthermore, mouse and human studies have occasionally come to contrasting conclusions, which has cast doubt on the effectiveness of lab mice in translational research (Fisher et al. 1996; Naqvi et al. 2019; Puellmann et al. 2006; Seok et al. 2013). Meanwhile, recent studies have indicated that genetic and environmental regularity in lab mice may be a potential cause of these discrepancies (Churchill et al. 2004; Viney et al. 2015). For instance, the majority of current immunological knowledge was primarily gleaned from a few inbred 
mouse strains, thereby limiting the amount of noise caused by segregating genetic variations. Thus, much of our biomedical knowledge, is built on a very small number of individual mice; this would correspond to only 5 to 10 human individuals, which would hardly be enough to emulate the complex genetic diversity and vulnerability of human beings (Pedersen and Babayah 2011). Moreover, together with genetic factors, the environmental variables of age, socioeconomic status, climate, nutritional status, health status, etc.-none of which can be accounted for in lab mice-have also been shown to affect human immune responses (Brodin et al. 2015; Rohr et al. 2011). Above all other environmental influencers, it has recently become clear that microbial communities, known as the microbiota, play an invaluable role in the physiology of hosts. Microbiota have been shown to influence processes from organ development/morphogenesis and metabolism to the development, differentiation, and function of host immunity (Belkaid and Hand 2014; Sommer and Bäckhed 2013). Indeed, germ-free (GF) mice, unexposed to microorganisms, have been found to exhibit a broad spectrum of developmental and functional impairment in the immune system, directly linked to susceptibility to various immunological disorders including cancer, allergies, inflammatory bowel disease (IBD), and autoimmune diseases (Round and Mazmanian 2009). There is therefore increasing demand in various areas of biomedical research to develop an alternative and/or complementary system for lab mice that can minimize the chasm between basic and translational research (Masopust et al. 2017; von Scheidt et al. 2017).

The study of wild mice seems to be an alluring alternative with which to compensate for the limited translational value of lab mice (Poh 2019; Nobs and Elinav 2019). In contrast to lab mice, wild or free-living mice exhibit preserved genetic diversity as well as environmental effects, which, as stated above, are the key determinants of human ecophysiology. Despite the extreme lack of research involving wild mice, previous studies have pinpointed human-like immunological traits in such mice—-for example, a 'primed' immune state and its potential link with the cumulative exposure to microbes in nature-compared with mice living in a laboratory vivarium (Table 1) (Abolins et al. 2017, 2011; Beura et al. 2016; Boysen et al. 2011; Lochmiller et al. 1991). Indeed, a recent study by Lalit and colleagues showed that immune systems in lab mice have phenocopied a human neonate-like immune status, compared with those of wild mice, in which human adult-like immune traits were observed (Beura et al. 2016). The unique immunological characteristics of feral mice are highly reminiscent of human immune traits, suggesting that wild mouse systems may be a potential tool to bridge the gap between lab mice and translational research. Studies have shown that wild mice have a complex and diverse microbiome, including a mycobiome, archaeome, and parasitome, similar to those found in humans (Table 2) (Beura et al. 2016; Lavrinienko et al. 2018; Linnenbrink et al. 2013; Rosshart et al. 2019, 2017; Song et al. 2021; Suzuki and Nachman 2016; Weldon et al. 2015; Williams et al. 2018). As the microbiome is known to configure host physiology and pathophysiology, the higher orders of the microbial communities in wild mice, shaped by natural selection in the wild, might play distinct roles in host fitness. For example, primed immune traits in wild mice have shown a strong association with age and infectious burden with remarkable heterogeneity (Abolins et al. 2017; Beura et al. 2016), indicating that cumulative microbial exposure may be one of the key drivers of immune activation/maturation in wild mice, in a manner similar to that seen in humans (Salgame et al. 2013; Virgin et al. 2009). Furthermore, the natural gut microbiota has been shown to improve the outcome of viral infection and tumorigenesis in lab mice (Rosshart et al. 2017). Although it would be somewhat premature to discuss the validity of the use of wild mice in current biomedical research, as very little research has yet been carried out, the studies cited above collectively highlight the potential of the wild mouse system as a tool in translational research that can better mimic the biological evolution of humans and diseases.

Human beings have co-evolved alongside trillions of microbes, considered to be a "hidden organ" due to their immense impact on human health and disease (Cho and Blaser 2012; O'Hara and Shanahan 2006; Pflughoeft and Versalovic 2012). Recent advances in microbiome research have outlined the indispensable roles of microbiota in the induction, training, and function of the host immune system in both humans as well as rodents (Belkaid and Hand 2014), and microbial exposure to acute and chronic pathogens has been shown to control immune variation in humans (Salgame et al. 2013; Virgin et al. 2009). In addition, individuals with a heavy helminth burden have been found to show compromised vaccination-induced immune responses with Bacillus Calmette-Guerin (BCG) and cholera (Cooper et al. 2001; Elias et al. 2001). Meanwhile, a number of studies have shown the versatility of microbiota in modulating host physiology and functions in rodent (Belkaid and Hand 2014; Round and Mazmanian 2009; Sommer and Bäckhed 2013; Surana and Kasper 2014). However, as the majority of lab mice are raised in an SPF vivarium, as a result of which they have extremely simple and controlled microbiota, the lack of microbial diversity and complexity in lab mice might be an environmental deficit that decreases the value of lab mice to human translational research. Indeed, recent studies have exquisitely demonstrated how the "dirty" microbiota from wild mice can be used as a tool to recapitulate naturally selected microbial niches to bolster the translational validity of lab mice (Beura et al. 2016; Rosshart et al. 2019, 2017). Lalit and colleagues were the first to show the potential 


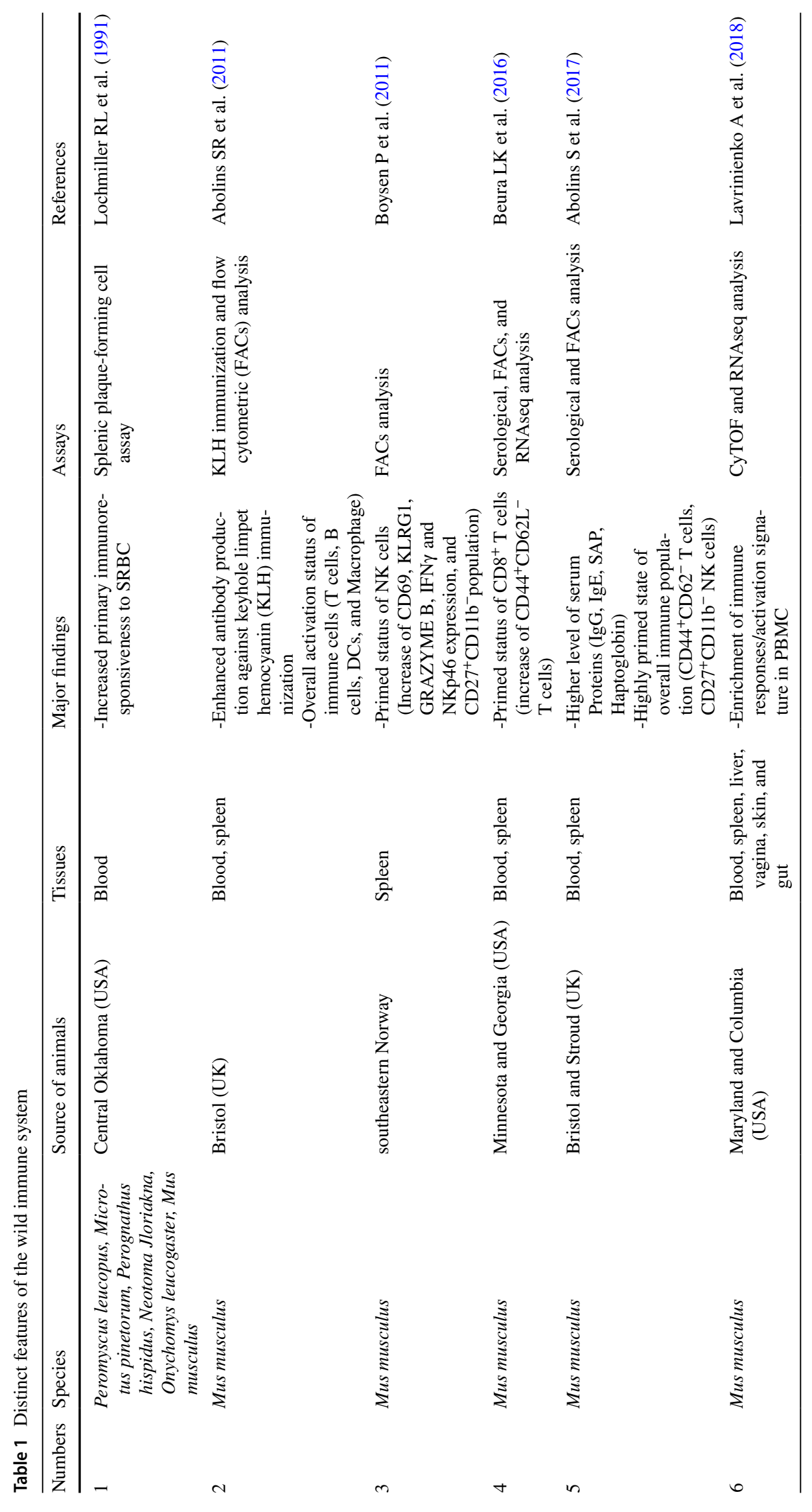




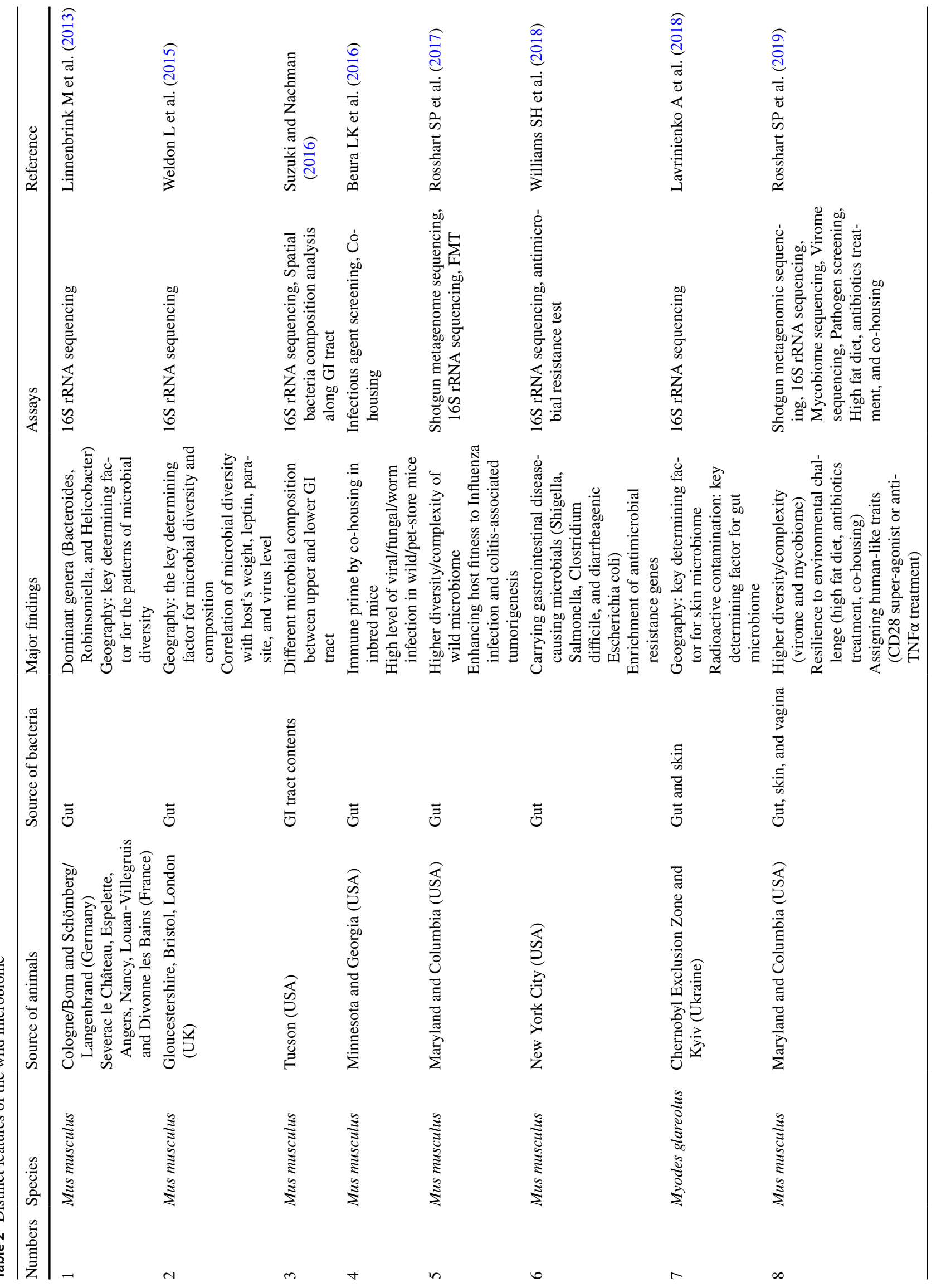


of dirty microbiota as a valuable tool in lab mouse-based immunology by co-housing pet-store mice with lab mice (Beura et al. 2016). Intriguingly, co-housing with pet-store mice was sufficient to increase the differentiated effector memory $\mathrm{T}$ cell population $\left(\mathrm{CD} 44^{\mathrm{hi}}\right)$, which produces high levels of Granzyme B, in the peripheral immune system of the lab mice. Moreover, the authors found de novo populating $\mathrm{CD}^{+} \mathrm{T}$ cells, which have a tissue-resident memory $\mathrm{T}$ cell $\left(\mathrm{T}_{\mathrm{RM}}\right)$ phenotype, in non-lymphoid organs of cohoused C57BL/6 mice, similar to those seen in human tissues. Finally, the transcriptional signatures in blood cells from the lab mice that were co-housed with pet-store mice were found to have reshaped signature patterns that more closely mirrored adult than neonatal ones. Altogether, these studies highlight that, beyond genetic elements, microbiota play a key role in determining basal immunological states, and suggest that dirty microbiota may be of use in restoring physiological microbial states and provoking immunological traits observed in human beings. Indeed, another study discovered that sequential infection with defined pathogens including herpesvirus, influenza, and helminth in lab mice elicited altered transcriptome signatures that partially recapitulated the immunological features triggered by dirty microbiota (Reese et al. 2016). This suggests that selective microbial exposure (termed "defined dirty") can be used to install human-like immunological traits in lab mice.

To study the importance of host-microbe interaction on host physiology, Rehermann's group at NIH has trapped more than 800 wild mice from eight different locations, characterized their gut microbiota and compared them with those of lab mice (Rosshart et al. 2017). As expected, wild mice exhibited more diverse and complex microbiome compositions with well-preserved natural features, including viral and fungal species, compared to those of lab mice. Interestingly, the wild microbiome can be transferred to, and maintained in, lab mice over several generations (up $5^{\text {th }}$ generation) without notable changes, suggesting that there is relatively minor impact of other environmental factors, including temperature, day/night cycle, diet, and social structure, on the microbiome community (Rosshart et al. 2019, 2017). Similar to these results, we have documented the resilience and stability of the wild microbiome in inbred mice up to the 15 th generation (unpublished data), strengthening the potential value of "dirty" microbiota in translational research.

The potential benefits of the wild microbiome to the fitness of lab mice have been evaluated in a disease context. Following influenza infection, compared with laboratory mice (lab) or laboratory microbiome-transferred mice (labR), wild microbiome-implanted mice (wildR) showed significantly decreased mortality (lab/labR: $83 \%$ vs. wildR: $8 \%$ ), viral burden, and lung pathology. Additionally, researchers have found that fecal microbiota transplantation (FMT) of wild mouse gut microbiota conferred protection 
against inflammation-induced neoplastic development. Altogether, these results suggest that the "natural microbiota" (microbiota from free-living mice and humans) have coevolved to promote host fitness and survival under natural selection pressure, to establish a symbiotic host-microbe interaction that is integral to host physiology, particularly in the case of the immune system. To take "natural microbiota" engraftment a step further, the same group devised a model in which they transferred C57BL/6 embryos into a pseudo-pregnant dam, captured in the wild (Rosshart et al. 2019). The pups from the wild dams, called "wildlings", were shown to retain much of the wild microbiota via vertical transmission from the wild dam, but with the less complex genetics of C57BL/6. In a manner similar to that of the natural microbiota engraftment system, wildlings have well-retained naturally derived microbiome compositions, such as those of the mycobiome and virome, that can be vertically transferred to their offspring for multiple generations without notable diversification, indicating the resilience of the natural microbiome. Next, they comprehensively profiled and compared the immune states of lab, wild, and wildling mice to estimate the contribution of genetics (wild vs. wildling) or microbiome (lab vs. wildling) on the host immune system by cytometry, using time of flight (CyTOF) and RNA sequencing-based transcriptome analysis (RNAseq). They found more similar transcriptome patterns of blood mononuclear cells from wildlings when compared with wild mice than lab mice, despite their genetic differences. Intriguingly, these researchers have shown the considerable influence of the microbiome on immune cells in central lymphoid tissue but not in non-lymphoid tissue, which indicates that genetics and microbial composition combine to influence host immunity. Finally, the translational value of wilding was evaluated by the retrospective validation of two well-known models, CD28-super-agonist (CD28SA) for the treatment of autoimmune disease, inflammatory disease, and transplantation (Puellmann et al. 2006) and anti-TNF $\alpha$ treatment for sepsis (Fisher et al. 1996), which have shown discordant results in lab mouse and human systems. Surprisingly, the treatment of CD28SA or anti-TNF $\alpha$ in wildlings, but not in lab mice, phenocopied the trait of immune responses observed in humans. Altogether, these results cast doubt on the validity of the current laboratory mouse system and suggest that wildlings may be a promising complement to lab mice for translational research in immunology.

In support of a wild/dirty/wildling system, Graham's research group at Princeton University has recently built an outdoor mouse enclosure with eight wedge-shaped pens covering nearly $1,500 \mathrm{~m}^{2}$, and has put lab mice in these "farms" to re-wild them in natural environments; such mice are termed "wilded". This enables researchers to manipulate the key determinants in animal-based biomedical research, such as host genetics, age, and sex, while preserving naturally occurring environmental pressure (Graham 2021; Leung et al. 2018). Interestingly, re-wilding of lab mice has been found to partially phenocopy the 'primed' immune traits that exist in wild mice and humans (Leung et al. 2018; Yeung et al. 2020). Furthermore, a recent study has beautifully outlined the relative contributions of genetic versus environmental factors that govern inflammatory immune responses by re-wilding lab mice carrying nod2 or atg $16 l 1$ mutations, the well-known susceptibility mutations in inflammatory bowel disease (Lin et al. 2020). Overall, their results suggest that re-wilding lab mice could facilitate exploration of the effects of the natural environment in wildlife.

While laboratory animal-based research has led to notable advances in modern biomedical research, it has become apparent that lab mice are not always reliable in recapitulating human physiology and pathophysiology. This has led to significant demand for a novel platform that can mitigate the flaws or limitations of the lab mouse system. Accordingly, recent studies involving wild, dirty, wildling, and wilded systems have proposed these as potential complementary systems that maximize the translational validity of lab mice. Nevertheless, despite having significant congruence with human physiology, wild mice may not be technically easy to incorporate into general biomedical research facilities due to difficulties with animal supplementation and maintenance. As an alternative to the use of wild mice, FMT of natural microbiota from dirty, wildling, and wilded mice has been shown to elicit the recapitulation of major human pathophysiological traits in lab mice and is a promising tool of potential use in translational research. However, the application of these systems in current biomedical research poses the following difficulties: firstly, as a result of naturally occurring infections, these animals pose biosecurity and zoonotic issues that restrict their husbandry to facilities with biosafety level 2 or higher; furthermore, there is a huge difference in the overall composition of the microbiome depending on the source of wild mice, which may potentially lead to discordant research outcomes when using these systems. Thus, while these systems may not serve as a substitute for the use of lab mice in current biomedical research, they can be of use in enhancing the validity and translational power of animal-based preclinical research in human physiology and pathophysiology.

Acknowledgements This research was supported by the Basic Science Research Program through the National Research Foundation of Korea (NRF) funded by the Ministry of Education (2019M3C9A6091949, 2019R1A6A1A03032869, and 2021R1A2C2004501) to H.K. Kwon and by the Korea Mouse Phenotyping Project (2013M3A9D5072550, 2014M3A9D5A01074636) of the National Research Foundation funded by the Ministry of Science and ICT to J.K. Seong. This study was partially supported by the Research Institute for Veterinary Science, Seoul National University. 


\section{Declarations}

Conflict of interest The authors declare no conflict of interest.

Open Access This article is licensed under a Creative Commons Attribution 4.0 International License, which permits use, sharing, adaptation, distribution and reproduction in any medium or format, as long as you give appropriate credit to the original author(s) and the source, provide a link to the Creative Commons licence, and indicate if changes were made. The images or other third party material in this article are included in the article's Creative Commons licence, unless indicated otherwise in a credit line to the material. If material is not included in the article's Creative Commons licence and your intended use is not permitted by statutory regulation or exceeds the permitted use, you will need to obtain permission directly from the copyright holder. To view a copy of this licence, visit http://creativecommons.org/licenses/by/4.0/.

\section{References}

Abolins S, King EC, Lazarou L, Weldon L, Hughes L, Drescher P, Raynes JG, Hafalla JCR, Viney ME, Riley EM (2017) The comparative immunology of wild and laboratory mice, Mus musculus domesticus. Nat Commun 8:14811

Abolins SR, Pocock MJ, Hafalla JC, Riley EM, Viney ME (2011) Measures of immune function of wild mice, Mus musculus. Mol Ecol 20:881-892

Belkaid Y, Hand TW (2014) Role of the microbiota in immunity and inflammation. Cell 157:121-141

Beura LK, Hamilton SE, Bi K, Schenkel JM, Odumade OA, Casey KA, Thompson EA, Fraser KA, Rosato PC, Filali-Mouhim A, Sekaly RP, Jenkins MK, Vezys V, Haining WN, Jameson SC, Masopust D (2016) Normalizing the environment recapitulates adult human immune traits in laboratory mice. Nature 532:512-516

Boysen P, Eide DM, Storest AK (2011) Natural killer cells in freeliving Mus musculus have a primed phenotype. Mol Ecol 20:5103-5110

Brodin P, Jojic V, Gao T, Bhattacharya S, Angel Cesar JL, Furman D, Shen-Orr S, Dekker Cornelia L, Swan Gary E, Butte Atul J, Maecker Holden T, Davis Mark M (2015) Variation in the human immune system is largely driven by non-heritable influences. Cell 160:37-47

Cho I, Blaser MJ (2012) The human microbiome: at the interface of health and disease. Nat Rev Genet 13:260-270

Churchill GA, Airey DC, Allayee H, Angel JM, Attie AD, Beatty J, Beavis WD, Belknap JK, Bennett B, Berrettini W, Bleich A, Bogue M, Broman KW, Buck KJ, Buckler E, Burmeister M, Chesler EJ, Cheverud JM, Clapcote S, Cook MN, Cox RD, Crabbe JC, Crusio WE, Darvasi A, Deschepper CF, Doerge RW, Farber CR, Forejt J, Gaile D, Garlow SJ, Geiger H, Gershenfeld H, Gordon T, Gu J, Gu W, de Haan G, Hayes NL, Heller C, Himmelbauer H, Hitzemann R, Hunter K, Hsu H-C, Iraqi FA, Ivandic B, Jacob HJ, Jansen RC, Jepsen KJ, Johnson DK, Johnson TE, Kempermann G, Kendziorski C, Kotb M, Kooy RF, Llamas B, Lammert F, Lassalle J-M, Lowenstein PR, Lu L, Lusis A, Manly KF, Marcucio R, Matthews D, Medrano JF, Miller DR, Mittleman G, Mock BA, Mogil JS, Montagutelli X, Morahan G, Morris DG, Mott R, Nadeau JH, Nagase H, Nowakowski RS, O'Hara BF, Osadchuk AV, Page GP, Paigen B, Paigen K, Palmer AA, Pan H-J, Peltonen-Palotie L, Peirce J, Pomp D, Pravenec M, Prows DR, Qi Z, Reeves RH, Roder J, Rosen GD, Schadt EE, Schalkwyk LC, Ze S, Shimomura K, Shou S, Sillanpää MJ, Siracusa LD, Snoeck H-W, Spearow JL, Svenson K, Tarantino LM, Threadgill D, Toth
LA, Valdar W, de Villena FP-M, Warden C, Whatley S, Williams RW, Wiltshire T, Yi N, Zhang D, Zhang M, Zou F, The Complex Trait C (2004) The collaborative cross, a community resource for the genetic analysis of complex traits. Nat Genet 36:1133-1137

Cooper PJ, Chico M, Sandoval C, Espinel I, Guevara A, Levine MM, Griffin GE, Nutman TB (2001) Human infection with Ascaris lumbricoides is associated with suppression of the interleukin-2 response to recombinant cholera toxin $\mathrm{B}$ subunit following vaccination with the live oral cholera vaccine CVD 103-HgR. Infect Immun 69:1574-1580

Elias D, Wolday D, Akuffo H, Petros B, Bronner U, Britton S (2001) Effect of deworming on human $\mathrm{T}$ cell responses to mycobacterial antigens in helminth-exposed individuals before and after bacille Calmette-Guérin (BCG) vaccination. Clin Exp Immunol 123:219-225

Fisher CJ, Agosti JM, Opal SM, Lowry SF, Balk RA, Sadoff JC, Abraham E, Schein RMH, Benjamin E (1996) Treatment of septic shock with the tumor necrosis factor receptor: $\mathrm{Fc}$ fusion protein. N Engl J Med 334:1697-1702

Graham AL (2021) Naturalizing mouse models for immunology. Nat Immunol 22:111-117

Kleinert M, Clemmensen C, Hofmann SM, Moore MC, Renner S, Woods SC, Huypens P, Beckers J, de Angelis MH, Schürmann A, Bakhti M, Klingenspor M, Heiman M, Cherrington AD, Ristow M, Lickert H, Wolf E, Havel PJ, Müller TD, Tschöp MH (2018) Animal models of obesity and diabetes mellitus. Nat Rev Endocrinol 14:140-162

Lavrinienko A, Tukalenko E, Mappes T, Watts PC (2018) Skin and gut microbiomes of a wild mammal respond to different environmental cues. Microbiome 6:209

Leung JM, Budischak SA, Chung The H, Hansen C, Bowcutt R, Neill R, Shellman M, Loke P, Graham AL (2018) Rapid environmental effects on gut nematode susceptibility in rewilded mice. PLoS Biol 16:e2004108

Lin JD, Devlin JC, Yeung F, McCauley C, Leung JM, Chen YH, Cronkite A, Hansen C, Drake-Dunn C, Ruggles KV, Cadwell K, Graham AL, Loke P (2020) Rewilding Nod2 and Atg1611 mutant mice uncovers genetic and environmental contributions to microbial responses and immune cell composition. Cell Host Microbe 27:830-840.e834

Linnenbrink M, Wang J, Hardouin EA, Künzel S, Metzler D, Baines JF (2013) The role of biogeography in shaping diversity of the intestinal microbiota in house mice. Mol Ecol 22:1904-1916

Lochmiller RL, Vestey MR, McMurry ST (1991) Primary immune responses of selected small mammal species to heterologous erythrocytes. Comp Biochem Physiol A Physiol 100:139-143

Mak IW, Evaniew N, Ghert M (2014) Lost in translation: animal models and clinical trials in cancer treatment. Am J Transl Res 6:114-118

Masopust D, Sivula CP, Jameson SC (2017) Of mice, dirty mice, and men: using mice to understand human immunology. J Immunol 199:383-388

Naqvi S, Godfrey AK, Hughes JF, Goodheart ML, Mitchell RN, Page DC (2019) Conservation, acquisition, and functional impact of sex-biased gene expression in mammals. Science 365:eaaw317

Nguyen TL, Vieira-Silva S, Liston A, Raes J (2015) How informative is the mouse for human gut microbiota research? Dis Model Mech 8:1-16

Nobs SP, Elinav E (2019) Walk on the wildling side. Science 365:444-445

O'Hara AM, Shanahan F (2006) The gut flora as a forgotten organ. EMBO Rep 7:688-693

Pedersen AB, Babayan SA (2011) Wild immunology. Mol Ecol $20: 872-880$

Pflughoeft KJ, Versalovic J (2012) Human microbiome in health and disease. Annu Rev Pathol 7:99-122 
Poh A (2019) Gone wildling: building a better lab mouse. Cancer Discov 9:1331

Puellmann K, Beham AW, Kaminski WE (2006) Cytokine storm and an anti-CD28 monoclonal antibody. N Engl J Med 355:25922593 (author reply 2593-2594)

Reese TA, Bi K, Kambal A, Filali-Mouhim A, Beura LK, Bürger MC, Pulendran B, Sekaly RP, Jameson SC, Masopust D, Haining WN, Virgin HW (2016) Sequential infection with common pathogens promotes human-like immune gene expression and altered vaccine response. Cell Host Microbe 19:713-719

Reza Khorramizadeh M, Saadat F (2020) Animal models for human disease. Animal Biotechnology, 2nd edn. Academic Press, Boston, pp 153-171. https://doi.org/10.1016/B978-0-12-811710-1. $00008-2$

Rohr JR, Dobson AP, Johnson PT, Kilpatrick AM, Paull SH, Raffel TR, Ruiz-Moreno D, Thomas MB (2011) Frontiers in climate changedisease research. Trends Ecol Evol 26:270-277

Rosshart SP, Herz J, Vassallo BG, Hunter A, Wall MK, Badger JH, McCulloch JA, Anastasakis DG, Sarshad AA, Leonardi I, Collins N, Blatter JA, Han S-J, Tamoutounour S, Potapova S, Foster St Claire MB, Yuan W, Sen SK, Dreier MS, Hild B, Hafner M, Wang D, Iliev ID, Belkaid Y, Trinchieri G, Rehermann B (2019) Laboratory mice born to wild mice have natural microbiota and model human immune responses. Science (New York, NY) 365:eaaw4361

Rosshart SP, Vassallo BG, Angeletti D, Hutchinson DS, Morgan AP, Takeda K, Hickman HD, McCulloch JA, Badger JH, Ajami NJ, Trinchieri G, Pardo-Manuel de Villena F, Yewdell JW, Rehermann B (2017) Wild mouse gut microbiota promotes host fitness and improves disease resistance. Cell 171:1015-1028.e1013

Round JL, Mazmanian SK (2009) The gut microbiota shapes intestinal immune responses during health and disease. Nat Rev Immunol 9:313-323

Rust JH (1982) Animal models for human diseases. Perspect Biol Med 25:662-672

Salgame P, Yap GS, Gause WC (2013) Effect of helminth-induced immunity on infections with microbial pathogens. Nat Immunol 14:1118-1126

Seok J, Warren HS, Cuenca AG, Mindrinos MN, Baker HV, Xu W, Richards DR, McDonald-Smith GP, Gao H, Hennessy L, Finnerty CC, López CM, Honari S, Moore EE, Minei JP, Cuschieri J, Bankey PE, Johnson JL, Sperry J, Nathens AB, Billiar TR, West MA, Jeschke MG, Klein MB, Gamelli RL, Gibran NS, Brownstein BH, Miller-Graziano C, Calvano SE, Mason PH, Cobb JP, Rahme LG,
Lowry SF, Maier RV, Moldawer LL, Herndon DN, Davis RW, Xiao W, Tompkins RG (2013) Genomic responses in mouse models poorly mimic human inflammatory diseases. Proc Natl Acad Sci 110:3507-3512

Sommer F, Bäckhed F (2013) The gut microbiota - masters of host development and physiology. Nat Rev Microbiol 11:227-238

Song H, Kim J, Guk J-H, Kim W-H, Nam H, Suh JG, Seong JK, Cho S (2021) Metagenomic analysis of the gut microbiota of wild mice, a newly identified reservoir of campylobacter. Front Cell Infect Microbiol. https://doi.org/10.3389/fcimb.2020.596149

Surana NK, Kasper DL (2014) Deciphering the tête-à-tête between the microbiota and the immune system. J Clin Invest 124:4197-4203

Suzuki TA, Nachman MW (2016) Spatial heterogeneity of gut microbial composition along the gastrointestinal tract in natural populations of house mice. PloS One 11:e0163720

Viney M, Lazarou L, Abolins S (2015) The laboratory mouse and wild immunology. Parasite Immunol 37:267-273

Virgin HW, Wherry EJ, Ahmed R (2009) Redefining chronic viral infection. Cell 138:30-50

von Scheidt M, Zhao Y, Kurt Z, Pan C, Zeng L, Yang X, Schunkert H, Lusis AJ (2017) Applications and limitations of mouse models for understanding human atherosclerosis. Cell Metab 25:248-261

Weldon L, Abolins S, Lenzi L, Bourne C, Riley EM, Viney M (2015) The gut microbiota of wild mice. PloS One 10:e0134643

Williams SH, Che X, Paulick A, Guo C, Lee B, Muller D, Uhlemann A-C, Lowy FD, Corrigan RM, Lipkin WI (2018) New York City house mice (Mus musculus) as potential reservoirs for pathogenic bacteria and antimicrobial resistance determinants. mBio 9:e00624-e00618

Wong CH, Siah KW, Lo AW (2019) Estimation of clinical trial success rates and related parameters. Biostatistics 20:273-286

Yeung F, Chen Y-H, Lin J-D, Leung JM, McCauley C, Devlin JC, Hansen C, Cronkite A, Stephens Z, Drake-Dunn C, Fulmer Y, Shopsin B, Ruggles KV, Round JL, Pn L, Graham AL, Cadwell $\mathrm{K}$ (2020) Altered immunity of laboratory mice in the natural environment is associated with fungal colonization. Cell Host Microbe 27:809-822.e806

Publisher's Note Springer Nature remains neutral with regard to jurisdictional claims in published maps and institutional affiliations. 